\title{
Neuroprotective Effect of a Prostacyclin Agonist (ONO-1301) with Thromboxane Synthase Inhibitory Activity in Rats Subjected to Cerebral Ischemia
}

\author{
Mai Hazekawa $^{1}$, Yoshiki Sakai ${ }^{2}$, Miyako Yoshida ${ }^{1}$, Tamami Haraguchi ${ }^{1}$, Takahiro Uchida ${ }^{1}$ \\ ${ }^{1}$ Department of Clinical Pharmaceutics, Faculty of Pharmaceutical Sciences, Mukogawa Women's University, Hyogo, Japan; ${ }^{2}$ Ono \\ Pharmaceutical Co., Ltd., Research Headquarters, Osaka, Japan. \\ Email: takahiro@mukogawa-u.ac.jp
}

Received June $18^{\text {th }}$, 2011; revised July $28^{\text {th }}, 2011$; accepted August $6^{\text {th }}, 2011$.

\begin{abstract}
ONO-1301 has been developed as a novel long-acting prostacyclin agonist with thromboxane synthase inhibitory activity. In the present study, we investigated the cerebroprotective effect of ONO-1301 on post-ischemic injury induced by cerebral ischemia in rats. ONO-1301 (1 and $10 \mathrm{mg} / \mathrm{kg})$ was administrated orally at reperfusion and then twice a day for 42 days. The cell damage induced by cerebral ischemia in the hippocampal CA1 was evaluated using both Nissl staining and proliferating cell nuclear antigen (PCNA) staining on the 42 days after cerebral ischemia. Activated astrocytes were evaluated using immunofluorescence staining with GFAP on the 42 days after cerebral ischemia. Spatial learning was assessed using a Morris water maze (MWM) task on the 56 days (i.e. after a 14 days washout period). ONO-1301treated rats (1 and $10 \mathrm{mg} / \mathrm{kg}$ ) significantly improved cell death in the hippocampal CA1, the number of PCNA-positive cells and astrocyte activation. The spatial learning of ONO-1301-treated rats compared with vehicle-treated rats in the MWM task. These results suggest that repeated treatment with oral ONO-1301 could prevent or limit post-ischemic brain damage. In particular, treatment with ONO-1301 within 7 days after ischemia is most effective to improve ischemic damage.
\end{abstract}

Keywords: ONO-1301, Prostacyclin Agonist, Neuroprotection, Cerebral Ischemia, Astrocytes

\section{Introduction}

ONO-1301 is a novel long-acting prostacyclin agonist with thromboxane synthase inhibitory activity. Unlike prostacyclin, ONO-1301 does not possess a five-membered ring or allylic alcohol in its molecular structure, making it more biologically and chemically stable. Its inhibitory effect on thromboxane synthetase is mediated by binding of thromboxane synthase to the 3-pyridine moiety and a carboxylic acid group in ONO-1301 [1].

Prostacyclin $\left(\mathrm{PGI}_{2}\right)$, produced in the vascular endothelium, is a potent vasodilator and a strong inhibitor of platelet aggregation [2-4]. Thromboxane $\mathrm{A}_{2}\left(\mathrm{TXA}_{2}\right)$ on the other hand, although also a powerful vasodilator, promotes platelet aggregation [3]. An imbalance of $\mathrm{PGI}_{2}$ and $\mathrm{TXA}_{2}$ may therefore result in vasospasm [5]. Experimental and clinical data have shown that $\mathrm{PGI}_{2}$ may reduce vasoconstriction elicited by subarachnoid hemor- rhage [6-9], and beneficial effects of low-dose prostacyclin infusion $(0.5 \mathrm{ng} / \mathrm{kg} / \mathrm{min})$ have been reported in severe traumatic brain injury $[10,11]$.

A prostaglandin analogue, beraprost sodium, is known to significantly increase tail nerve conduction velocity (NCV) in rats with streptozotocin (STZ)-induced diabetes [12]. In a previous study, we reported that ONO1301-loaded PLGA microspheres improved delayed NCV in the lower limb of STZ-induced diabetic rats [13], while in other studies, it has been reported that ONO1301 improves pulmonary hypertension [14,15], and attenuates pulmonary fibrosis [16]. However, the neuroprotective effect of ONO-1301 has not been clarified.

The purpose of this study was to investigate the neuroprotective effect of ONO-1301 in rats subjected to cerebral ischemia. We used a modification of the stroke model developed by Pulsinelli and Brierley [17], termed cerebral ischemia model. Firstly, plasma level of radio- 
activity derived from ${ }^{14} \mathrm{C}$-ONO-1301 was measured in rats treated orally (p.o.) with 1 and $10 \mathrm{mg} / \mathrm{kg}{ }^{14} \mathrm{C}-\mathrm{ONO}$ 1301 , in order to determine the pharmacokinetics of ONO-1301 in vivo. Then we examined the effect of 42 days post-ischemic ONO-1301 treatment on neuronal damage, expression of PCNA-positive cells and activated astrocytes in the hippocampal CA1 region using cerebral ischemia model. In order to investigate the protective effect of ONO-1301 on physiological function, spatial learning was assessed using the Morris water maze (MWM) task.

\section{Materials and Methods}

\subsection{Animals}

Male Wistar rats weighing $250-300 \mathrm{~g}$ were obtained from Charles River Japan Inc. (Hino, Japan), and were housed in groups of $4 / 5$ animals per cage in a temperature-controlled room $\left(23^{\circ} \mathrm{C} \pm 2^{\circ} \mathrm{C}\right)$ with a relative humidity of $60 \% \pm 10 \%$. The lights were on from 7:00 to 19:00. The animals had free access to food (CRF-1, Oriental Yeast Co., Ltd., Tokyo, Japan) and water. Experiments were conducted between 9:00 and 17:00. All procedures regarding animal care and use were carried out according to the regulations of the Experimental Animal Care and Use Committee of Mukogawa Women's University. All experiments conformed to the guidelines on the ethical use of animals of the Japanese Government Notification, and all efforts were made to minimize both the number of animals used and their suffering.

\subsection{Cerebral Ischemia}

Animals were subjected to cerebral ischemia according to a previously published method [18]. Rats were anaesthetized with intraperitoneal (i.p.) sodium pentobarbital $(35 \mathrm{mg} / \mathrm{kg})$ and immobilized in a stereotaxic apparatus (Type SR-6; Narishige Scientific Instrument Laboratories, Tokyo, Japan). The bilateral arteries beneath the alar foramina of the first vertebra were electrocoagulated using a bipolar coagulator (MICRO-3D; Mizuho Industrial Co., Tokyo, Japan). The following day the common carotid arteries were compressed using a Schwartz vessel clip $(1.7 \times 8 \mathrm{~mm}$ jaw; World Precision Instrument, Sarasota, FL, USA) to each artery, and cerebral circulation was interrupted for $10 \mathrm{~min}$. This was repeated once after a 1-min interval. Rats that did not demonstrate loss of their righting reflex during arterial occlusion were excluded from subsequent experiments.

Animals were randomly divided into seven groups: a sham-ischemia group treated with $0.5 \mathrm{w} / \mathrm{v} \%$ carboxymethyl cellulose solution for 8 days (8d Vehicle treatment group); 8 days post-ischemic ONO-1301 groups treated with $10 \mathrm{mg} / \mathrm{kg}$ p.o. (8d ONO-1301 $10 \mathrm{mg} / \mathrm{kg}$ treatment group); a sham-ischemia group treated with 0.5 $\mathrm{w} / \mathrm{v} \%$ carboxymethyl cellulose solution for 42 days $(42 \mathrm{~d}$ Sham treatment group); two 42 days post-ischemic ONO-1301 groups treated with 1 or $10 \mathrm{mg} / \mathrm{kg}$ p.o. $(42 \mathrm{~d}$ ONO-1301 $1 \mathrm{mg} / \mathrm{kg}, 10 \mathrm{mg} / \mathrm{kg}$ treatment group); a group treated post-ischemia with vehicle p.o. for 8 days and ONO-1301 $10 \mathrm{mg} / \mathrm{kg}$ p.o. for 34 days (34d ONO-1301 $10 \mathrm{mg} / \mathrm{kg}$ treatment group); and a vehicle-ischemia group treated with $0.5 \mathrm{w} / \mathrm{v} \%$ carboxymethyl cellulose solution for 42 days post-ischemic treatment $(42 \mathrm{~d}$ Vehicle treatment group). ONO-1301 or vehicle was administered once directly after reperfusion and twice a day thereafter.

\subsection{Measurement of Radioactivity}

${ }^{14} \mathrm{C}-\mathrm{ONO}-1301$ was synthesized at SEKISUI Medical Co., Ltd. (Tokyo, Japan). The specific activity was 1.028 $\mathrm{MBq} / \mathrm{mg}$. Plasma levels of radioactivity derived from ${ }^{14} \mathrm{C}$-ONO-1301 were measured after a single p.o. administration of 1 or $10 \mathrm{mg} / \mathrm{kg}{ }^{14} \mathrm{C}-\mathrm{ONO}-1301$. Blood was drawn from the inferior vena cava of four rats $0.16,0.50$, $1,2,3,4,6,8,10,24,36,72 \mathrm{~h}$ after a single p.o. administration. Plasma was directly analyzed by liquid scintillation counting (LSC). Radioactivity for all in a Tri-Carb $460 \mathrm{C}$ liquid scintillation counter obtained from Packard Instrument Company (USA) for at least 5 min or 100,000 counts. This specification was met for the sample aliquots that had radioactivity greater than $100 \mathrm{dpm}$. Scintillation counting data (cpm) were automatically corrected for counting efficiency using the external standardization technique and an instrument-stored quench curve generated from a series of sealed quenched standards.

\subsection{Fixation and Processing of Tissue for Histology}

Rats were killed by deep anaesthetization with pentobarbital (35 mg/kg, i.p.) and transcardial perfusion with cold heparinized saline, followed by perfusion of $4 \%$ paraformaldehyde. The brain was then removed from the skull and post-fixed overnight in paraformaldehyde, before being dehydrated and embedded in paraffin. Coronal sections $10-\mu \mathrm{m}$ thick were made using a rotary microtome. For hippocampal morphology, a 3.3-mm section was taken from the bregma [19].

\subsection{Histological Examination}

In order to assess cell damage in the hippocampus after cerebral ischemia, the number of surviving cells was counted in Nissl-stained hipocampal sections. Other representative coronal sections were stained with proliferating cell nuclear antigen (PCNA), or glial fibrillary acidic 
protein (GFAP). These sections were examined by light microscopy, and the neuronal density of CA1 neurons $\left(\right.$ per $\left.\mathrm{mm}^{2}\right)$ in the stratum pyramidale measured.

Immunohistochemical detection (PCNA and GFAP) of cell damage in paraffin-embedded brain sections was performed by the streptavidin-avitin-biotin-immunop-eroxidase complex method [20]. Briefly, 10- $\mu \mathrm{m}$ thin PCNAstained sections on poly-L-lysine-coated slides were deparaffinized and rehydrated. Endogenous peroxidase activity was blocked with $1 \% \mathrm{H}_{2} \mathrm{O}_{2}$ in $0.1 \mathrm{~mol} / \mathrm{L}$ Tris- $\mathrm{NaCl}$ (pH 7.4) for $30 \mathrm{~min}$. After incubation with $5 \%$ normal bovine serum albumin (BSA; Serologicals, GA, USA) for $1 \mathrm{~h}$ at $37^{\circ} \mathrm{C}$, sections were incubated overnight at $40^{\circ} \mathrm{C}$ with primary antibody mouse anti-rat PCNA (Dako Cytmation, Glostrup, Denmark) in 1\% BSA using a 1:50 dilution. Sections were then incubated with a biotinylated secondary antibody goat anti-mouse IgG (Dako Cytmation, Glostrup, Denmark) for $30 \mathrm{~min}$ at $37^{\circ} \mathrm{C}$ at a $1: 200$ dilution.

This was followed by incubation with streptavidin peroxidase $(1: 100)$ for $1 \mathrm{~h}$ and subsequent chromogen development with $0.5 \% 3,3$ '-diaminobenzedrine tetrahydrochloride (DAB) and $0.33 \% \mathrm{H}_{2} \mathrm{O}_{2}$ in $0.5 \mathrm{~mol} / \mathrm{L}$ Tris$\mathrm{NaCl}$ as substrate. The sections were counterstained with Harris Haematoxylin (H\&E), then dehydrated, mounted, and used as a positive control.

In the GFAP staining, rabbit anti-rat GFAP (Dako Cytmation, Glostrup, Denmark) was used as primary antibody. A biotinylated goat anti-rabbit IgG (Dako Cytmation, Glostrup, Denmark) was used as secondary antibody.

Damage was scored in the CA1 according to the method of Freund et al. [21]: normal (score 0). No positive cells detected; mild (score 1), $<20 \%$ positive cells; moderate (score 2), $20 \%$ - 50\% positive cells; severe (score 3), 50\% - 70\% positive cells; very severe (score 4), $>70 \%$ positive cells. The damage score (from 0 to 4 ) for each subfield was calculated as a mean of the damage score in all sections in which the subfield was present. The total hippocampal damage score was calculated as the sum of subfield damage scores.

\subsection{MWM Task for Spatial Learning}

The swimming pool (Neuroscience Inc.) was a circular water tank, $148 \mathrm{~cm}$ in diameter and $44 \mathrm{~cm}$ deep, which was modified according to Morris [22]. It was filled to a depth of $32 \mathrm{~cm}$ with clear water at a temperature of $23^{\circ} \mathrm{C}$ $\pm 2^{\circ} \mathrm{C}$. The test was performed with the illumination of a $100-\mathrm{W}$ bulb. A platform, $12 \mathrm{~cm}$ in diameter and $30 \mathrm{~cm}$ in height, was present inside the tank, its top surface being $0.5 \mathrm{~cm}$ below the surface of the water. The pool was located in a large test room, and surrounded by many cues external to the maze (e.g. the experimenter, ceiling lights, racks, etc.), which were visible from within the pool and could be used by the rat for spatial location. The positions of the cues were unchanged throughout the test period. The CCD camera, equipped with a personal computer, was used for behavioral analysis (AXIS-30, Neuroscience Inc).

Each rat received two trials daily for four consecutive days. A trial consisted of placing the rat by hand into the water facing the wall of the pool, at one of three starting positions (excluding the quadrant containing the platform). The pool was divided into sections (north: N, south: S, east: E, or west: W). The platform was located in a constant position in the middle of one quadrant and its location was the same for all rats. During each block of three trials, each rat started once at each of the three starting positions, but the sequence of the positions was selected at random. In each trial, the time taken to swim to the hidden platform was recorded; the cut-off time was $90 \mathrm{~s}$. If a rat found the platform, it was permitted to remain there for $30 \mathrm{~s}$. If a rat failed to find the platform within $90 \mathrm{~s}$, the rat was forced to remain on the platform for $30 \mathrm{~s}$. At the end of a trial, the rat was returned to its cage. The inter-trial interval time was approximately 30 min. The performance of the test animal in each trial was assessed by two parameters: swimming time and swimming distance, using the personal computer. Swimming speed was calculated by Swimming length (m) per Goal latency (s).

\subsection{Statistical Analysis}

Data of Figures 1-3 are expressed as mean \pm S.D. Data of Figures 4-6 are expressed as mean \pm S.E.M. Data on the number of CA1 pyramidal neurons and the amount of cell damage were analyzed by Bonferroni/Dunnett's test after one-way (repeated measures) analysis of variance (ANOVA). The scores of expressed PCNA-positive cells and activated astrocytes (GFAP-positive cells) were analyzed for statistical significance using the cumulative chi-square test. Goal latency and swimming length in the MWM task was evaluated by one-way ANOVA. SAS software (ReL.8.2 TS020.SAS Version 5.0; SAS Institute Inc.) and the Yukms statistics library (Yukms statistics library Version 5.0, Yukms Co. Ltd.) were used; $P$-values of less than 0.05 were considered to be statistically significant.

\section{Results}

\subsection{Pharmacokinetic Study of ONO-1301 in Intact Rats}

${ }^{14} \mathrm{C}$-ONO-1301-derived radioactivity was detected at all the time points through $72 \mathrm{~h}$ postdose. As shown in Figure 1 , the concentration of plasma $\mathrm{AUC}_{0-\infty}$ and $\mathrm{C}_{\max }$ of 
$10 \mathrm{mg} / \mathrm{kg}$ group were approximately 10 -fold greater than the plasma those of $1 \mathrm{mg} / \mathrm{kg}$ group (Table 1). The time at which the maximal concentration occurred $\left(\mathrm{T}_{\max }\right)$ was similar between $1 \mathrm{mg} / \mathrm{kg}$ and $10 \mathrm{mg} / \mathrm{kg}$ group. The elimination $\mathrm{T}_{1 / 2}$ of $1 \mathrm{mg} / \mathrm{kg}$ group $(8.9 \pm 4.1 \mathrm{~h})$ was greater than that of $10 \mathrm{mg} / \mathrm{kg}$ group $(5.1 \pm 1.7 \mathrm{~h})$ (Table 1; Figure 1).

\subsection{Effect of Post-Ischemic ONO-1301 \\ Treatment on Cell Death in the Hippocampal CA1 Region Following Cerebral Ischemia}

Nissl staining revealed pyknosis, eosinophilia, karyrrhexis, and chromosome condensation in the CA1 pyramidal neurons in the vehicle-ischemia group compared with the sham-ischemia group. Cerebral ischemia induced cell death in hippocampal CA1 pyramidal neurons.

The 8 days ONO-1301 treatments of $10 \mathrm{mg} / \mathrm{kg}$ significantly suppressed neuronal death compared with vehicle $(\mathrm{F}=21.89, P<0.01)$ (Left: $8 \mathrm{~d}$ Vehicle $11.0 \pm 6.0,8 \mathrm{~d}$ ONO-1301 10 mg/kg 90.9 \pm 53.7; Right: 8 d Vehicle 20.0 $\pm 39.0,8 \mathrm{~d}$ ONO-1301 $10 \mathrm{mg} / \mathrm{kg} 89.7 \pm 51.8$; Figure 2).

The 42 days ONO-1301 treatments ( 1 and $10 \mathrm{mg} / \mathrm{kg}$ ) significantly suppressed neuronal death $(\mathrm{F}=24.32, P<$

Table 1. The pharmacokinetics of ONO-1301 in rats following a single oral dose of 1 or $10 \mathrm{mg} / \mathrm{kg}$ ONO-1301 $(n=4)$.

\begin{tabular}{ccccc}
\hline $\begin{array}{c}\text { Dose } \\
(\mathrm{mg} / \mathrm{kg})\end{array}$ & $\begin{array}{c}\mathrm{C}_{\max } \\
(\mathrm{ng} \mathrm{cq} / \mathrm{ml})\end{array}$ & $\mathrm{T}_{\max }(\mathrm{h})$ & $\begin{array}{c}\mathrm{AUC}_{(0-\infty)} \\
(\mathrm{ng} \mathrm{cq} \cdot \mathrm{h} / \mathrm{ml})\end{array}$ & $\mathrm{T}_{1 / 2}(\mathrm{~h})$ \\
\hline 1 & $354 \pm 109$ & $1.5 \pm 0.6$ & $2325 \pm 604$ & $8.9 \pm 4.1$ \\
10 & $3981 \pm 1569$ & $1.5 \pm 0.6$ & $27586 \pm 9230$ & $5.1 \pm 1.7$ \\
\hline
\end{tabular}

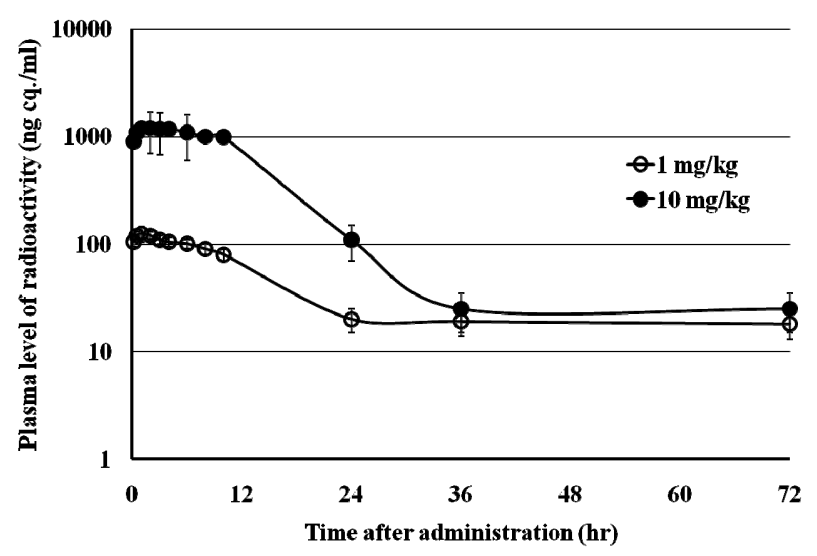

Figure 1. Plasma levels of radioactivity of derived from ${ }^{14} \mathrm{C}$ ONO-1301 after administration of ${ }^{14} \mathrm{C}$-ONO-1301 in intact rats. ${ }^{14} \mathrm{C}-\mathrm{ONO}-1301$ was administered orally to intact rats; plasma levels of radioactivity of derived from ${ }^{14} \mathrm{C}$-ONO1301 was detected in plasma for $72 \mathrm{~h}$ after a single injection $(\odot, 1 \mathrm{mg} / \mathrm{kg} ; \bullet, 10 \mathrm{mg} / \mathrm{kg})$. Values represent the mean \pm S.D. of 4 rats.
0.01 , and $P<0.05$ vs vehicle-ischemia group, respectively; Figure 3), as did the 34 days ONO-1301 $10 \mathrm{mg} /$ $\mathrm{kg}$ treatment $(P<0.05$ vs vehicle-ischemia group; Figure 3). The neuroprotective effect of the 42 days ONO1301 treatment was, however, greater than the 34 days ONO-1301 $10 \mathrm{mg} / \mathrm{kg}$ treatment (Left: 42d Sham $163.1 \pm$ $4.1,42 \mathrm{~d}$ Vehicle $24.0 \pm 7.5,42 \mathrm{~d}$ ONO-1301 $1 \mathrm{mg} / \mathrm{kg}$ $73.6 \pm 15.5,42 \mathrm{~d}$ ONO-1301 $10 \mathrm{mg} / \mathrm{kg} 91.2 \pm 14.2,34 \mathrm{~d}$ ONO-1301 $10 \mathrm{mg} / \mathrm{kg} 48.3 \pm 9.9$; Right: 42d Sham 162.3 $\pm 0.7,42 \mathrm{~d}$ Vehicle $19.6 \pm 4.5,42 \mathrm{~d}$ ONO-1301 $1 \mathrm{mg} / \mathrm{kg}$ $63.0 \pm 5.1,42 \mathrm{~d}$ ONO-1301 $10 \mathrm{mg} / \mathrm{kg} 76.4 \pm 4.9,34 \mathrm{~d}$ ONO-1301 10 mg/kg 43.2 \pm 4.7; Figure 3).

\subsection{Decrease of PCNA-Positive Cells Induced by Cerebral Ischemia}

There were significantly higher numbers of PCNA-positive cells in the vehicle-ischemia group compared with the sham-ischemia group $(P<0.01)$. The 42 days postischemic ONO-1301 treatment $(1 \mathrm{mg} / \mathrm{kg})$ significantly inhibited the expression of PCNA-positive cells induced by repeated cerebral ischemia $(\mathrm{F}=6.24, P<0.05$ vs $42 \mathrm{~d}$ Vehicle group). The number of PCNA-positive cells in

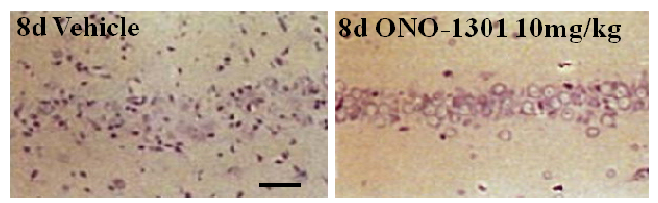

(a)

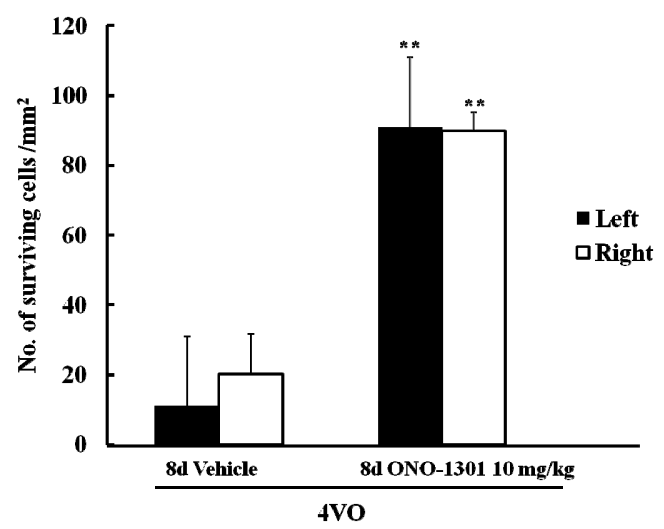

(b)

Figure 2. Effect of post-ischemic ONO-1301 8 days treatment on cell death in the hippocampal CA1 region following cerebral ischemia. Animals received ONO-1301 $10 \mathrm{mg} / \mathrm{kg}$ orally for 8 days after cerebral ischemia. In this figure, 4VO stands for four vessels occlusion. (a) Representative photographic results of surviving cells in the hippocampal CA1 region $\times 200$, bar $=25 \mu \mathrm{m}$. (b) Surviving cells in the CA1 region of the hippocampus expressed as number of cells/ $\mathrm{mm}^{2}$. **P<0.01 vs 8d Vehicle group (Bonferroni/Dunnett's test). The number of rats examined was 10/group. 


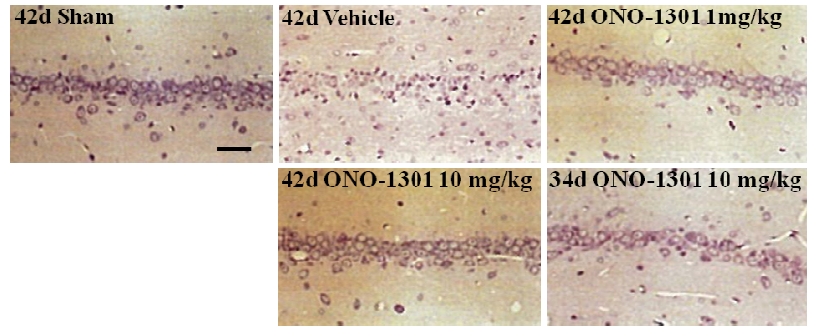

(a)

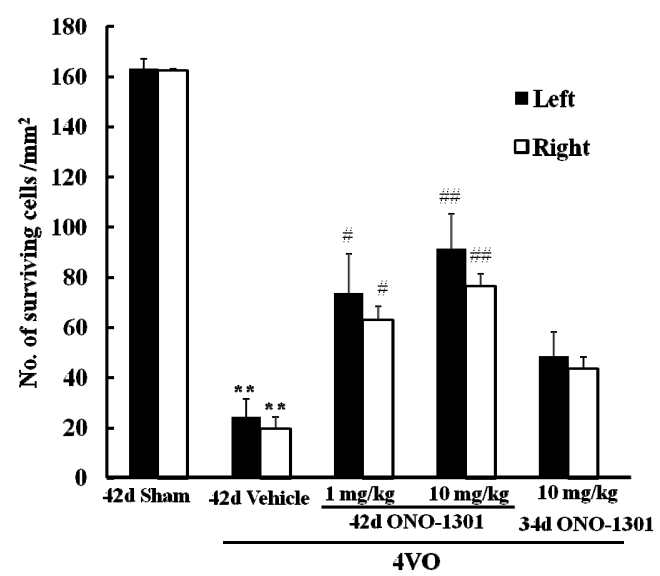

(b)

Figure 3. Effect of post-ischemic ONO-1301 42 days treatment on cell death in the hippocampal $\mathrm{CA1}$ region following cerebral ischemia. Animals received ONO-1301 1 or 10 $\mathbf{m g} / \mathbf{k g}$ orally for $\mathbf{4 2}$ days after cerebral ischemia. (a) Representative photographic results of surviving cells in the hippocampal CA1 region $\times 200$, bar $=25 \mu \mathrm{m}$; (b) Surviving cells in the CA1 region of the hippocampus expressed as number of cells $/ \mathrm{mm}^{2}$. ${ }^{*} \boldsymbol{P}<0.01$ vs $42 \mathrm{~d}$ Sham group; ${ }^{\#} \boldsymbol{P}<$ $0.05,{ }^{\#} P<0.01$ vs 42d Vehicle group (Bonferroni/Dunnett's test). The number of rats examined was $10-12$ /group.

each group was as follows: $42 \mathrm{~d}$ Sham $0.0 \pm 0.0,42 \mathrm{~d}$ Vehicle $2.0 \pm 0.2,42 \mathrm{~d}$ ONO- $13011 \mathrm{mg} / \mathrm{kg} 1.0 \pm 0.3,42 \mathrm{~d}$ ONO-1301 $10 \mathrm{mg} / \mathrm{kg} 1.2 \pm 0.3,34 \mathrm{~d}$ ONO-1301 10 $\mathrm{mg} / \mathrm{kg} 1.5 \pm 0.3$; Figure 4).

\subsection{Inhibition of Activated Astrocytes Induced by Cerebral Ischemia}

There were significantly higher numbers of GFAP- positive cells in the vehicle-ischemia group compared with the sham-ischemia group $(\mathrm{F}=12.51, P<0.01)$. The 42 days post-ischemic ONO-1301 treatment ( 1 or $10 \mathrm{mg} / \mathrm{kg}$ ) significantly inhibited the expression of GFAP-positive cells induced by repeated cerebral ischemia $(P<0.05$ vs vehicle group), whereas the 34 days ONO-1301 treatment did not inhibit activated astrocytes (42d Sham $0.0 \pm$ $0.0,42 \mathrm{~d}$ Vehicle $3.5 \pm 0.1,42 \mathrm{~d}$ ONO- $13011 \mathrm{mg} / \mathrm{kg} 1.9 \pm$ $0.4,42 \mathrm{~d}$ ONO- $130110 \mathrm{mg} / \mathrm{kg} 1.7 \pm 0.4,34 \mathrm{~d}$ ONO-1301 $10 \mathrm{mg} / \mathrm{kg} 2.5 \pm 0.4$; Figure 5).
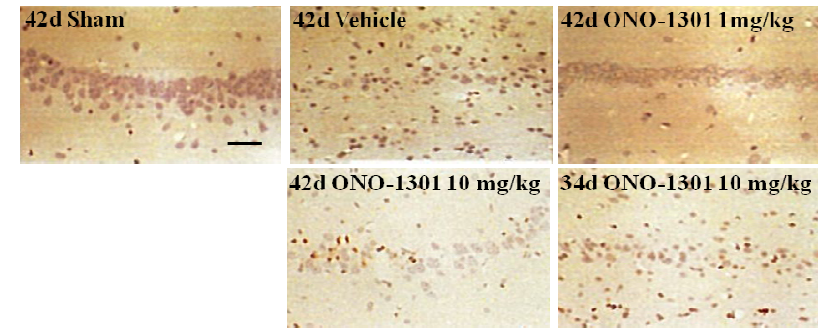

(a)

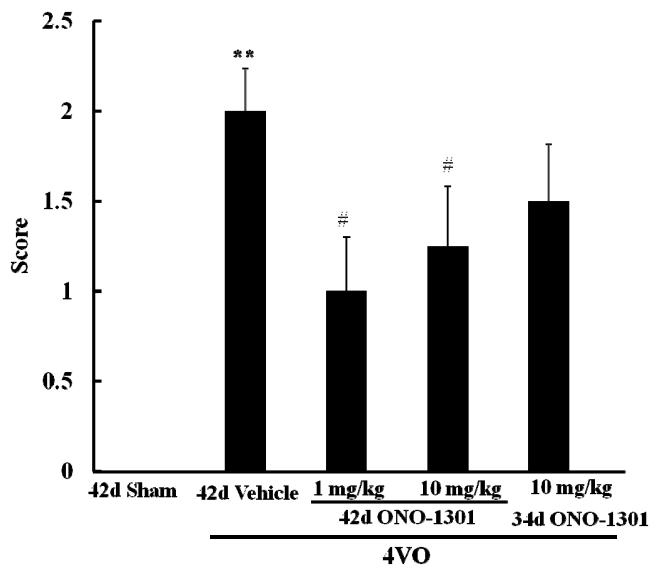

(b)

Figure 4. Effect of post-ischemic ONO-1301 treatment on presented PCNA-positive cells induced by cerebral ischemia. Animals received ONO-1301 1 or $10 \mathrm{mg} / \mathrm{kg}$ orally for 42 days after repeated cerebral ischemia. (a) Representative photographic results of PCNA-positive cell in the CA1 region of the hippocampus $\times 200$, bar $=25 \mu \mathrm{m}$; (b) PCNApositive cell in the CA1 region of the hippocampus expressed as number of cells $/ \mathrm{mm}^{2} . * * P<0.01$ vs $42 \mathrm{~d}$ Sham group; ${ }^{\#} P<0.05$ vs $42 \mathrm{~d}$ Vehicle group (chi-square test). The number of rats examined was $10-12$ group.

\subsection{Spatial Learning Using the MWM Task in Post-Ischemic Rats}

The MWM task was carried out on the 14 days after the end of the 42 days ONO-1301 treatment period. The repeated measure one-way ANOVA for goal latency showed a significantly delayed goal latency between the sham-ischemic and vehicle-ischemic groups $(\mathrm{F}=3.46, P$ $<0.01)$. The goal latency of 42 days ONO-1301-treated rats $(10 \mathrm{mg} / \mathrm{kg})$ was significantly improved compared with the vehicle-ischemic group $(P<0.01)$ with an average goal latency in eight time trials of: $42 \mathrm{~d}$ Sham 42.5 $\pm 2.2 \mathrm{~s}, 42 \mathrm{~d}$ Vehicle $58.4 \pm 1.9 \mathrm{~s}, 42 \mathrm{~d}$ ONO-1301 10 $\mathrm{mg} / \mathrm{kg} 47.9 \pm 2.3 \mathrm{~s}$, and $34 \mathrm{~d}$ ONO-1301 $10 \mathrm{mg} / \mathrm{kg} 51.7 \pm$ $2.2 \mathrm{~s}$; Figure 6(a). Furthermore, there was a significant difference between the swimming length of the shamischemic and vehicle-ischemic groups $(\mathrm{F}=4.05, P<$ 0.01). The swimming length of 42 days ONO-1301 treated 


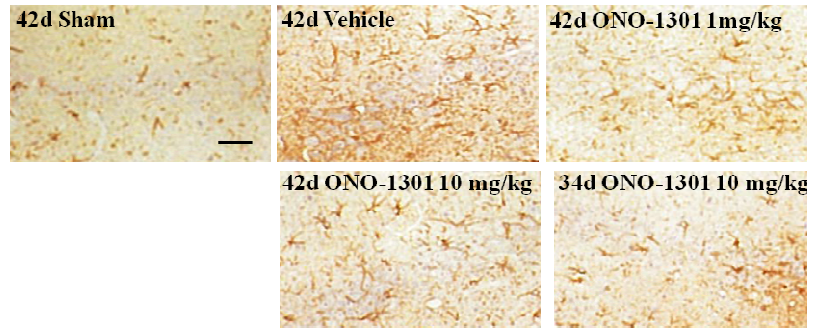

(a)

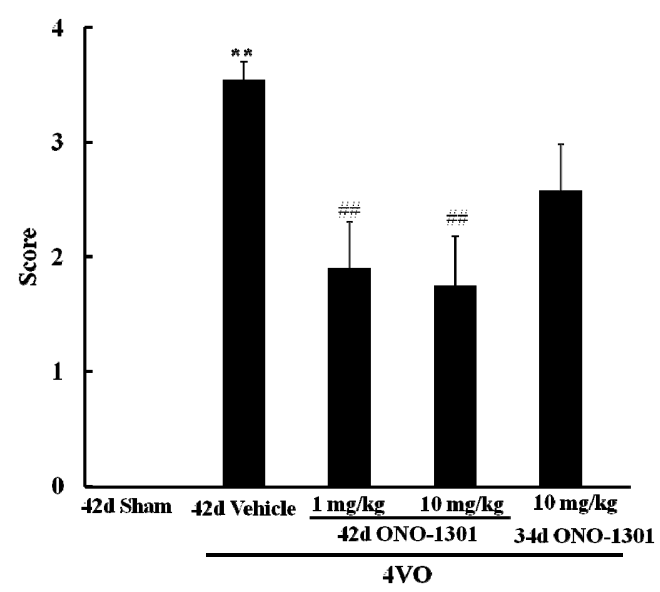

(b)

Figure 5. Effect of post-ischemic ONO-1301 treatment on activated astrocytes induced by cerebral ischemia. Animals received ONO-1301 1 or $10 \mathrm{mg} / \mathrm{kg}$ orally for 42 days after repeated cerebral ischemia. (a) Representative photographic results of GFAP-positive cell in the CA1 region of the hippocampus $\times 200$, bar $=25 \mu \mathrm{m}$. (b) GFAP-positive cell in the CA1 region of the hippocampus expressed as numbers cells $/ \mathrm{mm}^{2}$. ${ }^{* *} P<0.01$ vs $42 \mathrm{~d}$ Sham group; ${ }^{\# \#} P<0.01$ vs $42 \mathrm{~d}$ Vehicle group (cumulative chi-square test). The number of rats examined was $10-12$ /group.

rats was significantly less than the vehicle-ischemic group $(P<0.01)$ with average swimming times in eight time trials of: $42 \mathrm{~d}$ Sham $1068.9 \pm 53.8 \mathrm{~cm}, 42 \mathrm{~d}$ Vehicle $1500.7 \pm 47.4 \mathrm{~cm}, 42 \mathrm{~d}$ ONO-1301 $10 \mathrm{mg} / \mathrm{kg} 1172.7 \pm$ $57.9 \mathrm{~cm}, 34 \mathrm{~d}$ ONO-1301 $10 \mathrm{mg} / \mathrm{kg} 1267.1 \pm 53.9 \mathrm{~cm}$; Figure 6(b). Swimming speed during 4 groups was no significant differences (42d Sham $3.9 \pm 0.1 \mathrm{~m} / \mathrm{s}, 42 \mathrm{~d}$ Vehicle $3.9 \pm 0.1 \mathrm{~m} / \mathrm{s}, 42 \mathrm{~d}$ ONO-1301 $10 \mathrm{mg} / \mathrm{kg} 3.9 \pm 0.1$ $\mathrm{m} / \mathrm{s}, 34 \mathrm{~d}$ ONO-1301 $10 \mathrm{mg} / \mathrm{kg} 3.9 \pm 0.2 \mathrm{~m} / \mathrm{s}$ ).

\section{Discussion}

It has previously been reported that plasma ONO-1301 concentrations after a single subcutaneous administration indicated that its activity would be sustained [14]. In order to investigate the pharmacokinetics of ONO-1301 after oral administration, plasma level of radioactivity derived from ${ }^{14} \mathrm{C}$-ONO-1301 were measured after single oral doses of 1 and $10 \mathrm{mg} / \mathrm{kg}{ }^{14} \mathrm{C}-\mathrm{ONO}-1301$ in rats. In

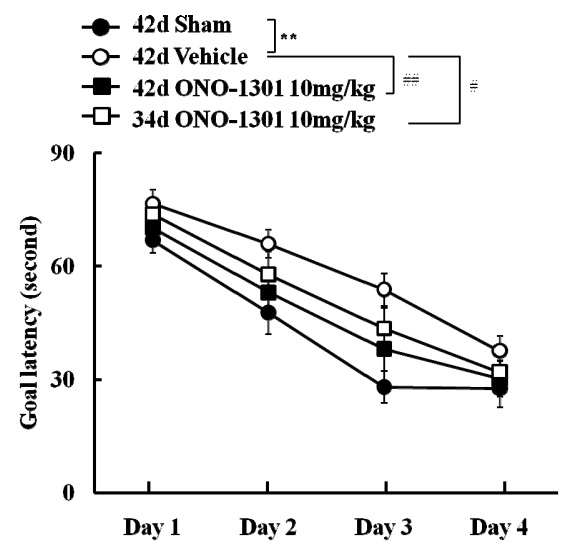

(a)

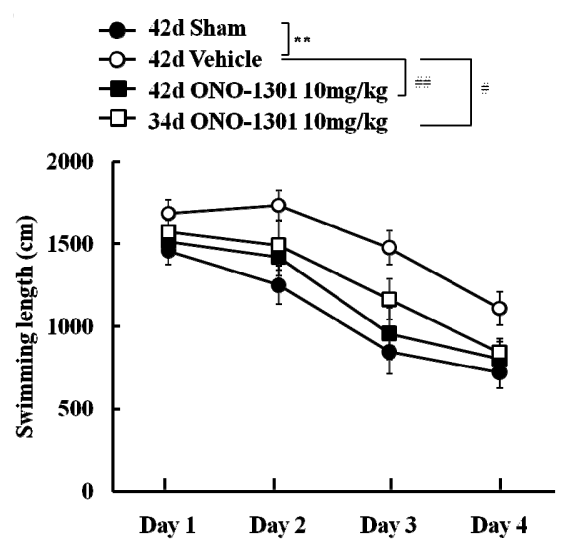

(b)

Figure 6. Spatial learning in the MWM task in rats with cerebral ischemia. The task was performed on the 14 days after the final treatment with ONO-1301 (10 mg/kg). Two trials were conducted per day for 4 days. (a) The data are given as mean \pm S.E.M. of goal latency time. (b) The data are given as mean \pm S.E.M. of swimming length. $* * P<0.01$ compared with 42d Sham group; ${ }^{\#} P<0.05,{ }^{\#} P<0.01$ compared with 42d Vehicle group (one-way ANOVA).

both 1 - and $10-\mathrm{mg} / \mathrm{kg}$ treatment group, the concentration of plasma $\mathrm{AUC}_{0-\infty}$ and $\mathrm{C}_{\max }$ of $10 \mathrm{mg} / \mathrm{kg}$ group were approximately 10 -fold greater than the plasma those of 1 $\mathrm{mg} / \mathrm{kg}$ group. These results suggested that the release profile of ONO-1301 showed a liner model. Liner model is known to easy to repeated treatment. Furthermore, plasma level of radioactivity of ONO-1301 is keep low levels without being zero $\mathrm{ng} \mathrm{cq} . / \mathrm{ml} 36 \mathrm{~h}$ after treatment of ONO-1301. These finding suggested ONO-1301 has possible to accumulate if ONO-1301 was repeated treatment for long term. However, in order to exert maximum neuroprotective effect, we decided ONO-1301 of treatment time is twice a day in this experimental schedule because $\mathrm{T}_{1 / 2}$ was about $5-8 \mathrm{~h}$.

In this study, twice-daily treatment with ONO-1301 
p.o. for 8 days after four-vessel occlusion (4VO) showed a neuroprotective effect against cerebral ischemia. Twice-daily treatment with ONO-1301 p.o. for 42 days also showed a neuroprotective effect against cerebral ischemia. However, twice-daily treatment with ONO-1301 p.o. for 34 days was no significant in neuroprotective effect. Previously study was reported $4 \mathrm{VO}$ model rat was shown two stage of neuronal cell death in ischemic damage process. First stage is acute neuronal cell death in hippocampus during 7 days after ischemia. Second stage is delayed progressive neuronal cell death as chronic stage [23-25]. In a previous study, it was reported that the therapeutic window for cannabidiol treatment to delay ischemic damage was determined by its inhibition of the inflammatory reaction, which was divided into three phases. Firstly, MPO-positive cells were expressed on 1 and 3 days after ischemia; secondly, microglia was activated on 1, 3, 7 and 14 days; and thirdly, astrocytes were activated on 7 and 14 days [26]. That is why, rats were treated vehicle for 8 days and ONO-1301 for 34 days. We determined hirtological and behavior change about neuron-protective effect of ONO-1301.

The histological changes taking place in the brain tissue were investigated by assessment of PCNA- and GFAP-positive cells. The 42 days ONO-1301 treatment inhibited expression of both PCNA-positive cells and the activated astrocyte reaction induced by repeated cerebral ischemia, while the 34 days ONO-1301 treatment did not inhibit the activated astrocyte reaction. These results suggested that the first 8 days after ischemia-reperfusion is the most important phase in which to inhibit activated astrocytes.

Neutrophil elastase is known to be released from activated neutrophils during the process of inflammation, elastase inhibitors exert a cardioprotective effect against reperfusion injury, probably by inhibition of leukocyte extravasation as indicated by the decrease in myeloperoxidase (MPO) activated within 7 days after ischemia [27]. Neutrophil elastase decreases the endothelial production of $\mathrm{PGI}_{2}$ through the inhibition of endothelial nitric oxide synthase (NOS) activation and thereby contributes to the development of ischemia-reperfusion- induced liver injury [28]. In these reports, $\mathrm{PGI}_{2}$ production is being regulated by two opposing effects after ischemia-reperfusion, being increased by noradrenaline and decreased by neutrophil elastase. The results of this study suggest that it is the $\mathrm{PGI}_{2}$-agonist effect of ONO-1301, rather than the $\mathrm{TXA}_{2}$-inhibitory effect, which is responsible for its neuroprotective effects. The neuroprotective mechanism of ONO-1301 is probably inhibited inframmation reaction of $\mathrm{PGI}_{2}$ such as suppress the neutrophil elastase activity in the first phase after ischemia-reper- fusion, as the histological results showed the 34 days ONO-1301 treatment group to have less effect than the 42 days ONO-1301 treatment group.

Cerebral ischemia induces cell death in the hippocampal CA1 pyramidal neurons, so the number of surviving CA1 pyramidal neurons gives a measure of the neuroprotective effect of ONO-1301. Treatment with ONO$1301(1$ and $10 \mathrm{mg} / \mathrm{kg})$ for 42 days post-ischemia was significantly suppressed neuronal death. We determined behavior change as spatial learning using MWM task. When spatial learning was assessed by the MWM task on the 14 days after the end of the 42 days ONO-1301 treatment period, the goal latency of 42 days ONO-1301treated rats was significantly improved compared with the vehicle-ischemia group. Furthermore, the swimming time of the 42 days ONO-1301-treated rats was significantly improved compared with the vehicle-ischemia group. While the goal latency and swimming time of 34 days ONO-1301 $10 \mathrm{mg} / \mathrm{kg}$ treatment group was also significantly improved compared with the vehicle-ischemia group. However, the improvement effect was less than that of the 42 days ONO-1301 treatment group. These results suggest that the critical phase for inhibition of the progressive inflammatory reaction (i.e., the therapeutic window) is less than 8 days after cerebral ischemia. Repeated treatment of ONO-1301 was indicated no affect to swimming ability and safety because swimming speed was no significant difference.

\section{Conclusions}

ONO-1301 has been developed as a novel long-acting $\mathrm{PGI}_{2}$ agonist with thromboxane synthase inhibitory activity. The primary finding of this study was ONO-1301 has neuroprotective effects when administered orally after experimentally induced cerebral ischemia. Daily treatment with oral ONO-1301 for 42 days post-ischemia prevented brain damage by inhibiting activated astrocytes. It was necessary to commence treatment with ONO-1301 within the 8 days period immediately following the ischemic insult. These findings suggest that ONO-1301 may be a clinically useful treatment if used soon after cerebrovascular accident.

\section{REFERENCES}

[1] T. Tanouchi, M. Kawamura, I. Ohyama, I. Kajiwara, Y. Iguchi, T. Okada, T. Miyamoto, K. Taniguchi, M. Hayashi, K. lizuka and M. Nakazawa, "Highly Selective Inhibitors of Thromboxane Synthetase. 2 Pyridine Derivatives," Journal of Medicinal Chemistry, Vol. 24, No. 10, 1981, pp. 1149-1155. doi:10.1021/jm00142a006

[2] G. A. FitzGerald, L. A. Friedman, I. Miyamori, J. O’Gray and P. J. Lewis, "A Double Blind Placebo Controlled 
Crossover Study of Prostacyclin in Man," Life Sciences, Vol. 25, No. 8, 1979, pp. 665-672. doi:10.1016/0024-3205(79)90507-1

[3] S. Moncada, R. Gryglewski, S. Bunting and J. R. Vane, "An Enzyme Isolated from Arteries Transforms Prostaglandin Endoperoxides to a Stable Substance That Inhibits Platelet Aggregation," Nature, Vol. 263, No. 5579, 1976, pp. 663-665. doi:10.1038/263663a0

[4] S. Mncada, E. A. Higgs and J. R. Vane, "Human Arterial and Venous Tissues Generate Prostacyclin (Prostaglandin $\mathrm{X}$ ), a Potent Inhibitor of Platelet Aggregation," Lancet, Vol. 1, No. 8001, 1977, pp. 18-20. doi:10.1016/S0140-6736(77)91655-5

[5] V. Seifert, D. Stolke, V. Kaever and H. Dietz, "Arachidonic Acid Metabolism Following Aneurysm Rupture. Evaluation of Cerebrospinal Fluid and Serum Concentration of 6-Keto-Prostaglandin F1 Alpha and Thromboxane B2 in Patients with Subarachnoid Hemorrhage," Surgical Neurology, Vol. 27, No. 3, 1987, pp. 243-252. doi:10.1016/0090-3019(87)90037-1

[6] D. J. Boullin, S. Bunting, W. P. Blaso, T. M. Hunt and S. Moncada, "Responses of Human and Baboon Arteries to Prostaglandin Endoperoxides and Biologically Generated and Synthetic Prostacyclin: Their Relevance to Cerebral Arterial Spasm in Man," British Journal of Clinical Pharmacology, Vol. 7, No. 2, 1979, pp. 139-147.

[7] L. Brandt, B. Ljunggren, K. E. Anderson, B. Hindfelt and T. Uski, "Effects of Indomethacin and Prostacyclin on Isolated Human Pial Arteries Contracted by CSF from Patients with Aneurysmal SAH," Journal of Neurosurgery, Vol. 55, No. 6, 1981, pp. 877-883. doi:10.3171/jns.1981.55.6.0877

[8] L. Brandt, B. Ljunggren, K. E. Andersson, B. Hindfelt and T. Uski, "Prostaglandin Metabolism and Prostacyclin in Cerebral Vasospasm," General Pharmacology, Vol. 14, No. 1, 1983, pp. 141-143. doi:10.1016/0306-3623(83)90085-X

[9] K. S. Paul, E. T. Whalley, C. Forster, R. Lye and J. Dutton, "Prostacyclin and Cerebral Vessel Relaxation," Journal of Neurosurgery, Vol. 57, No. 3, 1982, pp. 334-340. doi:10.3171/jns.1982.57.3.0334

[10] P. O. Grande, A. D. Möller, C. H. Nordeströn and U. Ungerstedt, "Low-Dose Prostacyclin in Treatment of Severe Brain Trauma Evaluated with Microdialysis and Jugular Bulb Oxygen Measurements," Acta Anaesthesiologica Scandinavica, Vol. 44, No. 7, 2000, pp. 886-894. doi:10.1034/j.1399-6576.2000.440718.x

[11] S. Naredi, M. Olivecrona, C. Lindgren, A. L. Ostlund, P. O. Grande and L. O. Koskinen, "An Outcome Study of Severe Traumatic Head Injury Using the 'Lund Therapy' with Low-Dose Prostacyclin," Acta Anaesthesiologica Scandinavica, Vol. 45, No. 4, 2001, pp. 402-426. doi:10.1034/j.1399-6576.2001.045004402.x

[12] N. Hotta, N. Koh, F. Sakakibara, J. Nakamura, Y. Hamada, T. Hara, K. Mori, E. Nakashima, K. Naruse, H. Fukasawa, H. Kakuta and N. Sakamoto, "Effects of Beraprost Sodium and Insulin on the Electroretinogram, Nerve
Conduction, and Nerve Blood Flow in Rats with Streptozotocin-Induced Diabetes," Diabetes, Vol. 45, No. 3, 1996, pp. 361-366. doi:10.2337/diabetes.45.3.361

[13] M. Hazekawa, Y. Sakai, M. Yoshida, T. Haraguchi, T. Morisaki and T. Uchida, "Preparation of ONO-1301Loaded PLGA Microspheres and Their Effect on Nerve Conduction Velocity," Journal of Pharmacy and Pharmacology, Vol. 63, No. 3, 2011, pp. 362-368. doi:10.1111/j.2042-7158.2010.01237.x

[14] M. Kataoka, N. Nagaya, T. Satoh, T. Itoh, S. Murakami, T. Iwase, Y. Miyahara, S. Kyotani, Y. Sakai, K. Kangawa and S. Ogawa, "A Long-Acting Prostacyclin Agonist with Thromboxane Inhibitory Activity for Pulmonary Hypertension," American Journal of Respiratory and Critical Care Medicine, Vol. 172, No. 12, 2005, pp. 1575-1580. doi:10.1164/rccm.200501-102OC

[15] H. Obata, Y. Sakai, S. Ohnishi, S. Takeshita, H. Mori, M. Kodama, K. Kangawa, Y. Aizawa and N. Nagaya, "Single Injection of a Sustained-Release Prostacyclin Analog Improves Pulmonary Hypertension in Rats," American Journal of Respiratory and Critical Care Medicine, Vol. 177, No. 2, 2008, pp. 195-201. doi:10.1164/rccm.200703-349OC

[16] S. Murakami, N. Nagaya, T. Itoh, M. Kataoka, T. Iwase, T. Horio, Y. Miyahara, Y. Sakai, K. Kangawa and H. Kikuma, "Prostacyclin Agonist with Thromboxane Synthase Inhibitory Activity (ONO-1301) Attenuates Bleomycin-Induced Pulmonary Fibrosis in Mice," American Journal of Physiology: Lung Cellular and Molecular, Vol. 290 , No. 1,2006 , pp. 59-65. doi:10.1152/ajplung.00042.2005

[17] W. A. Pulsinelli and J. B. Brierley, "A New Model of Bilateral Hemispheric Ischemia in the Unanesthetized Rat," Stroke, Vol. 10, No. 3, 1979, pp. 267-272. doi:10.1161/01.STR.10.3.267

[18] F. Pu, K. Mishima, K. Irie, K. Motohashi, Y. Tanaka, K. Orito, T. Egawa, Y. Kitamura, N. Egashira, K. Iwasaki and M. Fujiwara, "Neuroprotective Effects of Quercetin and Rutin on Spatial Memory Impairment in an 8-Arm Radial Maze Task and Neuronal Death Induced by Repeated Cerebral Ischemia in Rats," Journal of Pharmacological Sciences, Vol. 104, No. 4, 2007, pp. 329-334. doi:10.1254/jphs.FP0070247

[19] R. P. Ostrowski, A. R. Colohan and J. H. Zhang, "Mechanisms of Hyperbaric Oxygen-Induced Neuroprotection in a Rat Model of Subarachnoid Hemorrhage," Journal of Cerebral Blood Flow \& Metabolism, Vol. 25, No. 5, 2005, pp. 554-571. doi:10.1038/sj.jcbfm.9600048

[20] R. Jin, B. H. Bay, V. T. Chow, P. H. Tan and V. C. Lin, "Metallothionein 1E mRNA is Highly Expressed in Oestrogen Receptor-Negative Human Invasive Ductal Breast Cancer," British Journal of Cancer, Vol. 83, No. 3, 2000, pp. 319-323. doi:10.1054/bjoc.2000.1276

[21] T. F. Freund, A. Ylienen, R. Miettinen, A. Pitkanen, H. Lahtinen, K. G. Baimbridge and P. J. Riekkinen, "Pattern of Neuronal Death in the Rat Hippocampus after Status Epilepticus. Relationship to Calcium Binding Protein 
Content and Ischemic Vulnerability," Brain Research Bulletin, Vol. 28, No. 1, 1992, pp. 27-38. doi:10.1016/0361-9230(92)90227-O

[22] R. G. M. Morris, "Spiral Localization does Not Require the Presence of Local Cues," Learning and Motivation, Vol. 12, No. 2, 1981, pp. 239-260. doi:10.1016/0023-9690(81)90020-5

[23] H. Takamatsu, M. Tatsumi, S. Nitta, R. Ichise, K. Murakami, M. Iida, S. Nishikawa and K. Umemura, "Time Course of Progress to the Chronic Stage of Middle Cerebral Artery Occlusion Models in Rats," Experimental Brain Research, Vol. 146, No. 1, 2002, pp. 95-102. doi:10.1007/s00221-002-1147-0

[24] J. W. Ni, H. Ohta, K. Matsumoto and H. Watanabe, "Progressive Cognitive Impairment Following Chronic Cerebral Hypoperfusion Induced by Permanent Occlusion of Bilateral Carotid Arteries in Rats," Brain Research, Vol. 635, No. 1-2, 1994, pp. 231-236. doi:10.1016/0006-8993(94)90394-8

[25] H. Nakatomi, T. Kuriu, S. Okabe, S. Yamamoto, O. Hatano, N. Kawahara, A. Tamura, T. Kirino and M. Nakafuku, "Regeneration of Hippocampal Pyramidal Neurons after Ischemic Brain Injury by Recruitment of Endoge- nous Neuronal Progenitors," Cell, Vol. 110, No. 4, 2002, pp. 429-441. doi:10.1016/S0092-8674(02)00862-0

[26] K. Hayakawa, K. Irie, K. Sano, T. Watanabe, S. Higuchi, M. Enoki, T. Nakano, K. Harada, S. Ishikane, T. Ikeda, M. Fujioka, K. Orito, K. Iwasaki, K. Mishima and M. Fujiwara, "Therapeutic Time Window of Cannabidiol treatment on Delayed Ischemic Damage via High-Mobility Group Box1-Inhibition Mechanism," Biological \& Pharmaceutical Bulletin, Vol. 32, No. 9, 2009, pp. 1538-1544. doi:10.1248/bpb.32.1538

[27] C. P. Tiefenbacher, M. Ebert, F. Niroomand, S. Batkai, H. Tillmanns, R. Zimmermann and W. Kübler, "Inhibition of Elastase Improves Myocardial Function after Repetitive Ischemia and Myocardial Infarction in the Rat Heart," European Journal of Physiology, Vol. 433, No. 5, 1997, pp. 563-570. doi:10.1007/s004240050315

[28] M. Kawai, N. Harada, H. Takeyama and K. Okajima, "Neutrophil Elastase Contributes to the Development of Ischemia/Reperfusion-Induced Liver Injury by Decreasing the Production of Insulin-Like Growth Factor-I in Rats," Translational Research, Vol. 155, No. 6, 2010, pp. 294-304. doi:10.1016/j.trsl.2010.02.003 